\title{
Neem Biodiesel - A Sustainability Study
}

\author{
A. C. Lokesh'1, N. S. Mahesh'1, Balakrishna Gowda², Rajesh Kumar K ${ }^{3}$, Peter White ${ }^{4}$ \\ ${ }^{1}$ Mechanical and Manufacturing Engineering, M.S. Ramaiah School of Advanced Studies, Bangalore, 560058 \\ nsm@msrsas.org, lokesh@msrsas.org \\ ${ }^{2}$ Biofuel Park, Agriculture Research Station, Madenur, University of Agricultural Sciences, Hassan, 573220 \\ gowdabk@gmail.com \\ 3University of Agricultural Sciences, Bangalore 560068 \\ kodiraaju@yahoo.co.in \\ ${ }^{4}$ Faculty of Engineering and Computing, Coventry University, United Kingdom \\ mex096@coventry.ac.uk
}

\begin{abstract}
Azadiractha Indica (Neem) is one of the promising tree species suitable for providing oil for biodiesel production. This paper addresses the life cycle assessment (LCA) with respect to, global warming potential, acidification potential and energy balance of a small scale biodiesel system using Neem oil as feedstock, in rural Karnataka (a southern state in India). The environmental impacts have been bench marked with the life cycle impacts of fossil diesel system and Jatropha. Global warming potential of Neem biodiesel life cycle (338 $\mathrm{gCO}_{2}$-eq Functional Unit $\left.{ }^{1 *}\right)$ was found be 1.2 times higher than fossil

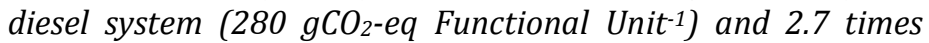
higher than Jatropha biodiesel system(123.7 gCO2-eq Functional Unit $^{-1}$ ). Acidification potential of Neem system was found to be negligible. It is observed that one hectare of Neem plantation is capable of sequestering the $1.35 t$ of biogenic $\mathrm{CO}_{2}$ released during the Neem biodiesel life cycle, with additional sequestration potential of $8.65 t \mathrm{CO}_{2} \mathrm{ha}^{-1}$. Net energy ratio of Neem biodiesel life cycle (22.06) has been found to be 26 times higher than fossil Diesel system and twelve times higher than Jatropha system (1.85). This life cycle study revealed that producing biodiesel from Neem oil is ecologically sustainable.
\end{abstract}

Keywords: Neem Biodiesel, Net Energy Ratio, Global Warming, LCA.

(C) Copyright 2014 Authors - This is an Open Access article published under the Creative Commons Attribution License terms (http://creativecommons.org/licenses/by/3.0). Unrestricted use, distribution, and reproduction in any medium are permitted, provided the original work is properly cited.

\section{Introduction}

Neem is an evergreen and deciduous tree with straight trunk and long spreading branches forming a broad round crown, growing to height of 12 to $18 \mathrm{~m}$. All parts of tree are bitter and the tree has religious significance. It is spread across the whole of South Asia. In India: Uttar Pradesh, Tamil-Nadu, Karnataka, Madhya Pradesh, Maharashtra, Andhra Pradesh, and Gujarat are important Neem producing states [2].

Neem is one of the most valuable trees in India. It has many commercially exploited by-products. The tree is medicinally valuable, because of its anti-allergic, antifungal, insecticidal, anti-dermatic, anti-inflammatory properties etc. In forestry, Neem is recommended for aforestation of dry areas, soil conservation, reclamation of alkaline soils and along avenues for shade and ornamental purposes $[8,10,17]$.

Neem is propagated both by seed and by vegetative methods. At the onset of the rains the seedlings are planted in the field. Planting distances of $5.5 \times 5.5 \mathrm{~m}$ (330 plants ha- 1 ) is a common practice. Oneyear-old seedlings are best suited for transplanting; around 2-3 kg of farmyard manure is mixed with soil during planting. Seedlings are irrigated depending on the climatic conditions in the first two years $[10,17]$.

Neem grows in full sun and is relatively a low maintenance tree once established. It is resistant to high winds and drought [9]. The rate of growth of Neem is found to be rapid up to the age of 5 years (after which, it slows down). The plant attains a height of $4 \mathrm{~m}$ at 5 years and reaches $10 \mathrm{~m}$ by 25 years. The mean annual girth increment is 2.3 to $3 \mathrm{~cm}$. It is one of the promising tree species suitable for providing oil for biodiesel production, which conforms to international standards. Oil percentage in Neem kernel varies from 18-25\%. In addition, the seed cake is also found to have 7-12\% residual oil, which can be extracted through solvent extraction $[2,10]$. 
Neem oil is light brown to dark brown in colour and bitter in taste with a strong peanut and garlic odour. The bitter taste and odour are due to presence of large amount of triterpenoid compounds like azadirachtin. Neem cake is the by-product of the Neem oil industry. It is used as organic manure. It works as a good nematicide hence, used in fields infested with nematodes. Since being organic in origin it has little impact on soil quality, but very effective in controlling / eradicating nematodes, which cause huge loss in banana plantation [7].

The list of tree borne oil (TBO) species has been constantly increasing. Many clean development mechanism project developers are interested in exploiting these tree species for meeting challenges of energy supply and green house gas (GHG) emission reduction. With TBO species number increasing, a scientific approach to identify environmentally sustainable tree species is considered as need of the hour [22].

A vital requirement for bio-fuels to be a sustainable alternative fuels is that, it should be produced from renewable feedstock with a lower negative environmental impact. Consequently, a study is needed in order to infer whether above requirements are met. Life cycle assessment (LCA) method has been found to be suitable for evaluating the environmental impact of biodiesel produced from vegetable oils [21].

In this paper, an exclusive LCA of a small-scale biodiesel production system using Neem oil in rural Karnataka has been presented. The LCA compares the performance of the Neem system with fossil fuel, and Jatropha biodiesel.

\section{Materials and Methods}

The Neem biodiesel system was assessed using LCA method according to the International Organization for Standardization procedures (ISO 14010/44:2006). The goal of this LCA study was to assess the sustainability of biodiesel production form Neem oil, for different life cycle stages and the overall life cycle under following impact categories:

1. Global Warming Potential $\left(\mathrm{CO}_{2}\right.$-eq)

2. Acidification Potential ( $\mathrm{SO}_{2}$-eq)

3. Energy Input and Output analysis (MJ)

\subsection{Life Cycle Inventory}

This LCA study was carried out at 'Biofuel Park', Agriculture Research Station (ARS) located at Madenur in Hassan district of Karnataka State. Biofuel Park project has been successful in establishing 465 Farmers associations for growing biodiesel feedstock called "Jaivika Indhana Beejagala Belegarara Sangha" (which means 'Biofuel Seed Growers Association' in local Kannada language) and covers about 70 villages designated as "Complete Biofuel Village" [8].

Hassan is situated 934 meters above mean sea level and located between $12^{\circ} 13^{\prime}$ and $13^{\circ} 33^{\prime}$ North latitudes and $75^{\circ} 33^{\prime}$ and $76^{\circ} 38^{\prime}$ East longitude. This district covers $6826.15 \mathrm{~km}^{2}$. It is divided into 8 taluks, 38 hoblies \& 2369 villages. The geography is mixed with the mountainous region to the West and South-West called 'Bisle Ghat' and the plains regions in the North, South and East. There are some areas of degraded forest ranges in central portion of the district [8].

\subsection{Phases of Neem Biodiesel Life Cycle}

The LCA of the Neem system included (Fig. 1).

(i) Cultivation phase: This phase includes, raising seedlings in poly bags in a nursery, transporting it to planting site, digging pits, filling pits with local farm yard manure, planting the seedlings, providing life saving irrigation in summer months for first two years and harvesting fruits for oil extraction after 5 to 6 years, energy input-output and associated emissions.

(ii) Oil extraction phase: This phase includes transportation of seeds to oil extraction unit, energy input-output and associated emissions.

(iii) Esterification phase: This phase includes conversion of oil into biodiesel, chemicals used and energy input, output and associated emissions.

(iv) Combustion / usage phase: This phase includes combusting biodiesel in an engine, its associated energy and emission

Allocation procedure is the method of dividing the input or output flows of a process to a system under research. The ISO standards allow inclusion of byproducts within the system boundaries. In case this byproduct substitutes a product usage in the system, it avoids the conventional production of substituted product. The environmental load of this avoided production process can be subtracted from the environmental burden of the system under research (e.g. in biodiesel production seed cake is a by-product, used as organic fertilizer. By-products, i.e. Neem seed cake (organic manure) and glycerine have been credited for 
synthetic fertiliser and glycerine, which are a by-product of fossil fuel system (Fig.2). The LCA study focuses on the usage of by-products and the biodiesel locally. One mega joule $(1 \mathrm{MJ})$ of energy available in $27 \mathrm{~g}$ Neem biodiesel (Fig.1) was considered as the functional unit (FU) for life cycle impact assessment. This study concentrated on the Neem plantations on wastelands, degraded lands and agricultural land bunds and community lands. The boundary conditions of LCA studies of Neem biodiesel in comparison with fossil fuel has been depicted in figure 1 and 2.

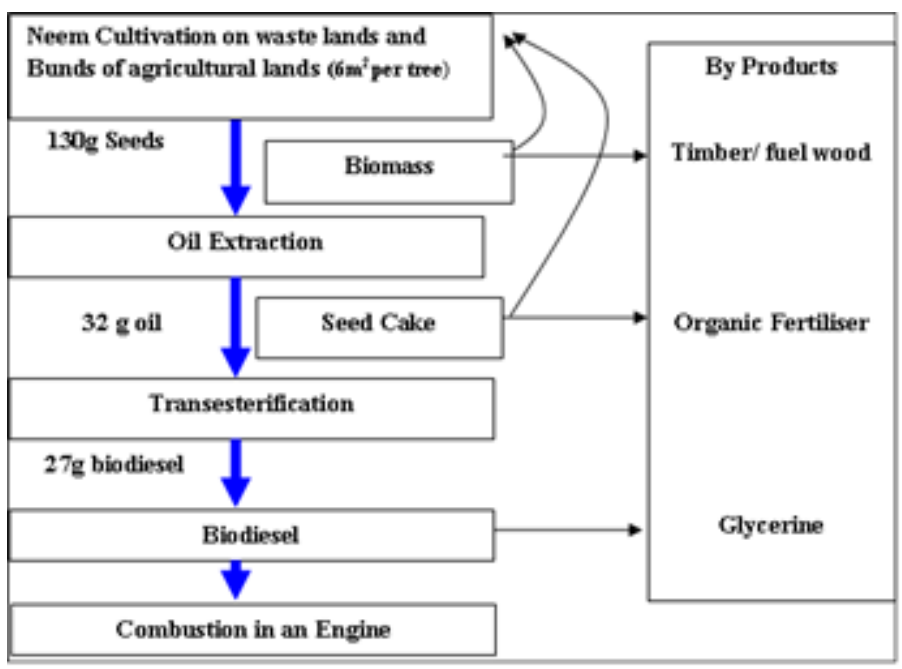

Figure 1. System boundary for Neem LCA.

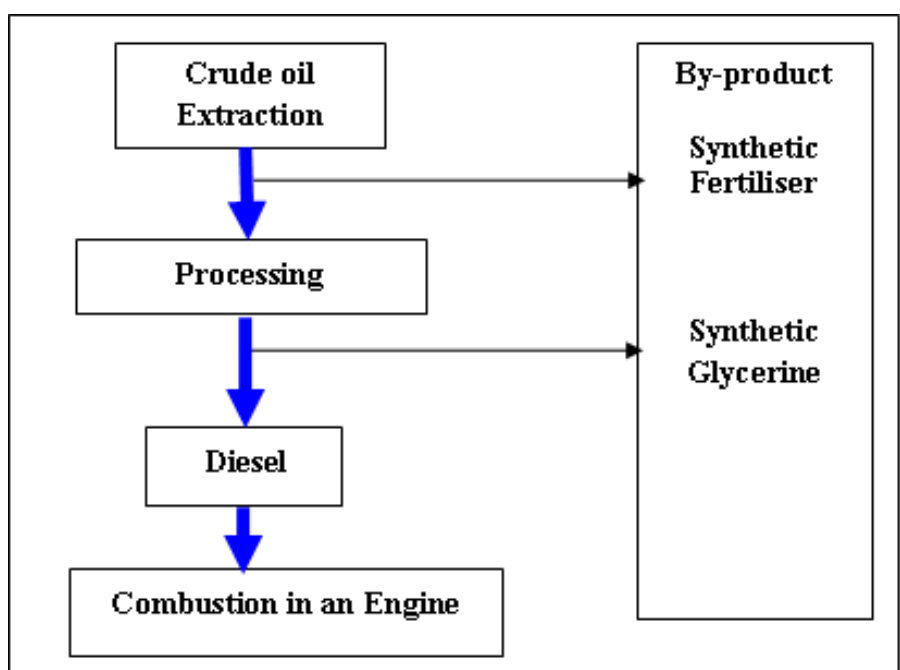

Figure 2. System boundary for fossil fuel- Diesel (reference).

\subsection{Data Collection and Analysis}

The data was collected by personal interviews and interaction with farmers associations for calculating the, global warming potential, acidification potential and energy input and output (MJ).
To asses the global warming potential and acidification potential of the Neem system, the associated input factors mentioned in table.1were considered and duly assessed. System-specific data (e.g. fertilizer use) were collected from Biofuel Park records while general data (e.g. field emission rates: $\mathrm{N}_{2} \mathrm{O}, \mathrm{NH}_{3}$ and $\mathrm{N}$ leaching from fertilisers applied to soil were taken from IPCC default factors and FAO) (IPCC-ID: 1622, IPCCID: 417274 \& FAO 2013), background data (e.g. production impact of fertilizer) were collected from literature and databases. Automobile emission data was collected from literature and reports of automotive research association of India, Pune [1].

The data pertaining to energy inputs and output were collected from Biofuel Park. The means by which, inputs were transported to the system and intermediate outputs transported between different systems phases have been accounted for. The transport distances of the inputs (seedlings, fertilizers, seeds, equipment and machines) were collected by interacting with farmers, understanding their agronomical practices.

Table 1. Information collected for LCA studies.

\begin{tabular}{|c|c|}
\hline Cultivation & Data \\
\hline Nursery practices & $\begin{array}{l}\text { Poly-bag use, water use, } \\
\text { fertilizer use, machinery use }\end{array}$ \\
\hline Field Preparation & Machinery Use \\
\hline Field in puts & $\begin{array}{l}\text { Seedlings per hectare, fertilizer } \\
\text { use }\end{array}$ \\
\hline $\begin{array}{l}\text { Plantation } \\
\text { management }\end{array}$ & $\begin{array}{l}\text { Irrigation, fertilizer, weeding } \\
\text { and harvest practices }\end{array}$ \\
\hline Yield & kg seeds / ha / yr \\
\hline Origin of inputs & Machinery, fertilizer \\
\hline Transport distances & Machinery, fertilizer, seeds \\
\hline Oil Extraction & Data \\
\hline Extraction rate & Oil \% / kg seed \\
\hline Oil press & $\begin{array}{l}\text { Capacity and energy } \\
\text { consumption }\end{array}$ \\
\hline Filter Press & $\begin{array}{l}\text { Capacity and energy } \\
\text { consumption }\end{array}$ \\
\hline By-product \& use & Seed cake/ $\mathrm{kg}$ of seed \\
\hline $\begin{array}{l}\text { Biodiesel } \\
\text { Production }\end{array}$ & Data \\
\hline $\begin{array}{l}\text { Transesterification } \\
\text { practices }\end{array}$ & Reagents and catalyst use \\
\hline By-product & Glycerine \\
\hline Combustion & Energy and emission \\
\hline
\end{tabular}




\subsection{Fossil Fuel as Reference System}

For a suitable life cycle comparison, the reference system (Fossil fuel) must provide the same products and functions as the biodiesel system evaluated [24]. Hence, all products and by-products of the biodiesel system should be substituted in the reference system. The substitutions reflect the local situation. Glycerine was considered the only by-product because the other byproducts are ploughed back to the field as soil enrichment and are not system outputs (Fig. 1). In the reference system the glycerine is substituted for synthetically produced glycerine of similar quality (Fig. 3).

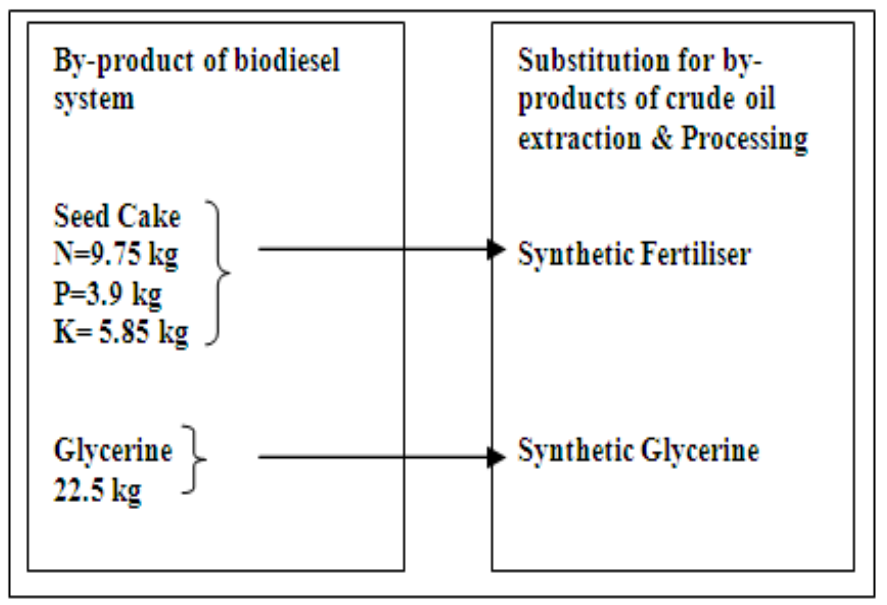

Figure 3. By-product Substitution of biodiesel system with reference system (Fossil Diesel).

\section{Results and Discussion}

\subsection{Global Warming Potential (GWP)}

The Neem biodiesel system showed a total emission of $338.2 \mathrm{~g} \mathrm{CO}_{2}$-eq Functional Unit ${ }^{-1}$ of which $293 \mathrm{~g} \mathrm{CO}_{2}$ was found to be biogenic (Ref. Table 2), which was found to be on par with $\mathrm{CO}_{2}$ emission of fossil fuel (280 g CO$_{2}$-eq Functional Unit ${ }^{-1}$ ) and 1.8 times higher than Jatropha (159.3 g CO$_{2}$-eq Functional Unit ${ }^{-1}$ ) [25]. This higher emission of $\mathrm{CO}_{2}$-eq in Neem biodiesel is attributed to wood burnt as fuel in its life cycle [25]. The cultivation phase $(90 \%)$ is the biggest contributor for GWP in the system followed by esterification (5.2\%) and oil extraction (4.8\%). Although very little inorganic fertilizer is used in the system, the GWP is found to be twice than Jatropha system evaluated by Achten et al [25], which uses a considerably higher amount of inorganic fertilizer and pesticides for better yield.

Neem wood is not preferred as fuel, since it has good timber value. GWP in absence of fuel wood, would result in the total emission of $45.72 \mathrm{gCO}_{2}$-eq Functional Unit $^{-1}$, which would be six times lower than fossil diesel system (280gCO2-eq Functional Unit ${ }^{-1}$ ) and three times lower than Jatropha biodiesel system(123.7 gCO2-eq Functional Unit-1).

As per calculations made from the data collected, a five / six year old Neem plantation has a $\mathrm{CO}_{2}$ sequestration capacity of about $10 \mathrm{t}^{\mathrm{h}} \mathrm{h}^{-1}$ year $^{-1}$ (Ref.Appendix-1). The biogenic $\mathrm{CO}_{2}$ emission from Neem system is 1.35 tons ha-1 (Ref. Table 2). The standing biomass of Neem trees on wasteland can sequester this biogenic $\mathrm{CO}_{2}$ emission and can further sequester additional 8.65 tons of $\mathrm{CO}_{2}$.

Out of the total $1561011.7 \mathrm{~g} \mathrm{CO}_{2}$ emission from Neem biodiesel life cycle, biogenic $\mathrm{CO}_{2}$ amounts to $1352724.8 \mathrm{~g}$ or $293 \mathrm{~g} \mathrm{CO}_{2}$ functional unit-1 (Biogenic $\mathrm{CO}_{2}$ is derived from summation of $\mathrm{CO}_{2}$ emission from biological inputs i.e. FYM application $[60 \mathrm{~g}]+$ Fuel wood burning [1350000g] + Biodiesel combustion $[2664.75 \mathrm{~g}]=1352724.8 \mathrm{~g})$.

\subsection{Acidification Potential (AP)}

The Neem system showed a 95\% decrease in AP compared to the reference system. The biggest contribution is due to diesel combustion for transportation during cultivation phase, which is very negligible compared to Jatropha system evaluated by [25]. Eutrophication potential has not been considered, since direct application of inorganic fertilizer and pesticides is not practiced in the system and in view of the fact that acidification potential results are quite negligible per functional unit (Table 3). 
Table 2. Global Warming Potential (CO2-eq.) in the life cycle of Neem biodiesel system.

\section{Cultivation Phase}

\begin{tabular}{|c|c|c|c|c|c|c|c|}
\hline Particulars & $\begin{array}{l}\text { Quantity } \mathrm{Yr}^{-} \\
{ }^{1} \mathrm{ha}^{-1}\end{array}$ & Unit & $\begin{array}{l}\mathrm{CO}_{2} \\
\text { emission }\end{array}$ & Unit & $\mathrm{gCO}_{2}$ eq ha- & $\begin{array}{l}\mathrm{gCO}_{2} \\
\mathrm{eq} \\
\mathrm{FU}^{-1}\end{array}$ & $\begin{array}{l}\text { References } \\
\text { For } \mathrm{CO}_{2} \\
\text { emission }\end{array}$ \\
\hline $\begin{array}{l}\text { Poly-bags } \\
\text { production \& } \\
\text { discharge }\end{array}$ & 1.65 & $\mathrm{~kg}$ & 5.50 & $\mathrm{~kg}$ & 9075.00 & & {$[14,16]$} \\
\hline $\begin{array}{l}\text { FYM } \\
\text { application } 1 \mathrm{t}\left(\mathrm{N}_{2} \mathrm{O}\right. \\
\text { Emission) }\end{array}$ & 6.00 & $\mathrm{~kg}$ & 0.01 & $\mathrm{~kg}$ & 60.00 & & [12] \\
\hline Diesel Use & 140 & $\mathrm{~km}$ & 0.33 & $\mathrm{~kg} / \mathrm{km}$ & 46620 & & [1] \\
\hline Fuel wood & 3000 & $\mathrm{~kg}$ & 0.45 & $\mathrm{~kg} / \mathrm{kg}$ & 1350000 & & \\
\hline Sub Total & & & & & 1405755 & 304.58 & \\
\hline
\end{tabular}

\section{Oil Extraction Phase}

Electricity

production

74800*

+ Filter press

74800

16.21

Sub Total

74800

Methanol

2992.00*

production

Electricity

production

and use: -

transesterification

unit

74800.00*

Biodiesel

Combustion

in Engine

(B100)

127.5

$\mathrm{kg}$

20.9

$\mathrm{g} / \mathrm{kg}$

2664.75

Sub Total

80456.75

17.43

Total

1561011.75

338.22

* Adopted from Achten et al. 2010.

For Global Warming Potential analysis, a six-year-old plantation is considered.

A six-year-old one ha plantation is estimated to yield around $600 \mathrm{~kg}$ seeds. 
Table 3. Acidification Potential ( $\mathrm{SO}_{2}$-eq.) in the life cycle of Neem biodiesel.

Cultivation Phase

\begin{tabular}{|c|c|c|c|c|c|c|c|}
\hline Particulars & $\begin{array}{l}\text { Quantity } \\
/ \mathrm{Yr} / \mathrm{ha}\end{array}$ & Unit & $\begin{array}{l}* * \text { SO2 } \\
\text { Emission }\end{array}$ & Unit & $\mathrm{gSO}_{2} \mathrm{eq} / \mathrm{ha}$ & $\begin{array}{l}\mathrm{gSO}_{2} \mathrm{eq} \\
/ \mathrm{FU}\end{array}$ & $\begin{array}{l}\text { References for } \\
\text { SO2 } \\
\text { Emission }\end{array}$ \\
\hline $\begin{array}{l}\mathrm{N} \text {-volatilization } \\
\text { from } 1 \text { tonne } \mathrm{FYM}\end{array}$ & 0.31 & $\mathrm{~kg}$ & 0.93 & $\mathrm{~g} \mathrm{~kg}^{-1}$ & 0.29 & & [6] \\
\hline $\begin{array}{l}\text { Poly bag } \\
\text { Production \& } \\
\text { Discharge- } \mathrm{SO}_{2} \\
\text { (330 units) }\end{array}$ & 1.65 & $\mathrm{~kg}$ & 71.40 & $\mathrm{~g} \mathrm{~kg}^{-1}$ & 117.81 & & {$[14,16]$} \\
\hline $\begin{array}{l}\text { Poly bag } \\
\text { Production \& } \\
\text { Discharge- } \mathrm{NO}_{x} \\
\text { (330 units) }\end{array}$ & 1.65 & $\mathrm{~kg}$ & 126.00 & $\mathrm{~g} \mathrm{~kg}^{-1}$ & 207.90 & & {$[14,16]$} \\
\hline Diesel Use $\mathrm{NO}_{\mathrm{x}}$ & 210 & $\mathrm{~km}$ & 0.40 & $\begin{array}{l}\mathrm{kg} \\
\mathrm{km}^{-1}\end{array}$ & 91.14 & & [1] \\
\hline Sub Total & & & & & 417.14 & 0.09 & \\
\hline
\end{tabular}

Oil Extraction Phase

Electricity production and use- Oil press +

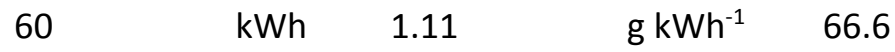
[12] Filter Press

\begin{tabular}{|c|c|c|c|c|c|c|c|}
\hline Sub Total & & & & & 66.6 & 0.01 & \\
\hline \multicolumn{8}{|l|}{ Esterification Phase } \\
\hline $\begin{array}{l}\text { Electricity } \\
\text { production and } \\
\text { use- } \\
\text { transesterification } \\
\text { unit }\end{array}$ & 35.29 & $\mathrm{kWh}$ & 1.11 & $\mathrm{~g} \mathrm{kWh}^{-1}$ & 39.22 & & [13] \\
\hline $\begin{array}{l}\text { Biodiesel } \\
\text { Combustion } \\
\text { in Engine } \\
\text { ( B100) }\end{array}$ & 127.5 & $\mathrm{~kg}$ & 0.001 & $\mathrm{~g} \mathrm{~kg}^{-1}$ & 0.13 & & {$[3,20]$} \\
\hline Sub Total & & & & & 39.35 & 0.01 & \\
\hline Total & & & & & $523 . .17$ & 0.11 & \\
\hline
\end{tabular}

\subsection{Energy Analysis}

Energy input is found to be $0.61 \mathrm{MJ}$ Functional Unit -1 (Ref. Table 4) and the output is found to be $13.46 \mathrm{MJ}$
Functional Unit -1 (Ref. Table 5). Net energy gain is found to be $12.85 \mathrm{MJ}$ Functional Unit-1 (Ref. Table 6).

Energy output per functional unit is found to be very high (13.46 MJ) compared to Jatropha system 
(0.4MJ) analyzed by Achten et al. [25]. Net energy ratio was found to be 22.06, which is twelve times higher than Jatropha and Diesel (Ref. Table 6). Lower energy output in Jatropha may be attributed to lower seed yield in rain fed conditions, higher plant population, and higher energy inputs in the form of inorganic fertiliser and pesticides [25].

Table 4. Energy inputs into Neem biodiesel system.

\begin{tabular}{|c|c|c|c|c|c|}
\hline Cultivation Phase & $\begin{array}{l}\text { Quantity } \\
\text { / Yr / ha }\end{array}$ & Units & $\begin{array}{l}\text { Calorific* } \\
\text { value in MJ }\end{array}$ & $\begin{array}{l}\text { Energy in } \\
\text { MJ }\end{array}$ & $\begin{array}{l}\text { Energy in } \\
\text { MJ / FU }\end{array}$ \\
\hline \multicolumn{6}{|l|}{ Man } \\
\hline Diesel & 22.00 & litres & 37.50 & 825.00 & \\
\hline FYM & 600.00 & $\mathrm{~kg}$ & 0.03 & 18.18 & \\
\hline \multicolumn{5}{|l|}{ Poly bag } & \\
\hline Sub Total & & & & 1182.46 & 0.26 \\
\hline \multicolumn{6}{|c|}{ Oil Extraction Phase } \\
\hline $\begin{array}{l}\text { Man } \\
\text { power }\end{array}$ & 6.00 & Man days & 10.00 & 60.00 & \\
\hline Diesel & 11.00 & litres & 37.50 & 412.5 & \\
\hline $\begin{array}{l}\text { Electricity } \\
\text { used }\end{array}$ & 60.00 & $\mathrm{kWh}$ & 3.60 & 216 & \\
\hline Sub Total & & & & 688.5 & 0.15 \\
\hline \multicolumn{6}{|c|}{ Esterification Phase } \\
\hline $\begin{array}{l}\text { Man } \\
\text { power }\end{array}$ & 4.00 & & 10.00 & 40.00 & \\
\hline $\begin{array}{l}\text { Electricity } \\
\text { used }\end{array}$ & 35.29 & & 3.60 & 127.05 & \\
\hline $\mathrm{NaOH}$ & 1.50 & & 23.30 & 34.95 & \\
\hline $\mathrm{H}_{2} \mathrm{SO}_{4}$ & 0.30 & & 3.00 & 0.90 & \\
\hline Acetic Acid & 0.30 & & 13.00 & 3.90 & \\
\hline Methanol & 37.50 & & 13.23 & 496.12 & \\
\hline Sub Total & & & & 702.93 & 0.15 \\
\hline Total & & & & 2573.89 & 0.05 \\
\hline \multicolumn{4}{|c|}{ Miscellaneous Energy inputs (Assumption $10 \%$ of Total Energy ) } & 257.39 & 0.06 \\
\hline \multicolumn{4}{|c|}{ Grand Total } & 2831.28 & $0.61^{¥}$ \\
\hline
\end{tabular}

${ }^{*}$ Calorific values adopted are universal

$¥$ Input energy required for producing $130 \mathrm{~g}$ Neem seeds $=0.13 \mathrm{~kg} \times 2831.28 / 600 \mathrm{~kg}^{\mathrm{seed} \mathrm{h}} \mathrm{h}^{-1}=0.61 \mathrm{MJ}$ 
Table 5. Energy outputs from Neem biodiesel system.

\begin{tabular}{lccllll}
\hline Cultivation Phase & & & & \\
\hline Energy & $\begin{array}{l}\text { Quantity } \\
\text { / Yr / ha }\end{array}$ & Units & $\begin{array}{l}\text { Calorific } \\
\text { value in MJ } \\
* *\end{array}$ & $\begin{array}{l}\text { Energy } \\
\text { in MJ }\end{array}$ & $\begin{array}{l}\text { Energy in } \\
\text { MJ / FU }\end{array}$ & Reference** $^{* *}$ \\
\hline $\begin{array}{l}\text { Seed } \\
\begin{array}{l}\text { Wood / } \\
\text { Timber } ¥\end{array}\end{array}$ & 600.00 & $\mathrm{~kg}$ & & 0 & & \\
\hline Sub Total & 3000.00 & $\mathrm{~kg}$ & 19.25 & 57750 & & {$[5]$} \\
\hline
\end{tabular}

Oil

Extraction

\begin{tabular}{llllll}
\hline Oil & 150.00 & $\mathrm{~kg}$ & NA & NA & NA \\
Seed cake & 390.00 & $\mathrm{~kg}$ & NA & NA & NA \\
\hline Sub Total & & & & 0 & 0.00 \\
\hline
\end{tabular}

\section{Esterification}

\begin{tabular}{lllllll}
\hline Biodiesel & 127.50 & $\mathrm{~kg}$ & 37.00 & 4717.50 & & {$[19,21]$} \\
Glycerine & 22.50 & $\mathrm{~kg}$ & 18.50 & 416.25 & & {$[15]$} \\
\hline Sub Total & & & & 5133.75 & 1.11 & \\
\hline Grand Total & & & & 62133.75 & 13.46 & \\
\hline
\end{tabular}

*Energy output from oil extraction phase has not been considered since oil is used for biodiesel production in esterification phase.

${ }^{¥}$ Neem wood, is not harvested for fuel; but for timber. However, considering its final disposal at the end of its life cycle (i.e. through burning) the energy output has been calculated.

Table 6. Net energy gain \& Net energy ratio.

\begin{tabular}{|c|c|c|c|}
\hline & Neem & Jatropha* & Diesel* $^{*}$ \\
\hline Net Energy Gain in MJ functional unit ${ }^{-1}$ & 12.85 & 0.19 & 0.18 \\
\hline Net Energy Ratio & 22.06 & 1.85 & 0.85 \\
\hline
\end{tabular}

*Achten et al. 2010

LCA studies revealed that producing biodiesel from Neem oil is ecologically sustainable (due to its high CO2 sequestration potential). Neem being a tree species from local ecology, it has very little impact on global warming and higher energy ratio compared to Jatropha. Planting Neem trees on wasteland triggers an improvement in higher storage capacity in terms of biomass, structure and biodiversity than the wasteland.

Unlike Jatropha, which has been debated to invade cultivable land and create food fuel conflict, Neem's invasion into cultivable land as main crop is ruled out because of its perennial nature with life span way above 90 years. Hence, this tree serves as a sustainable biodiesel feedstock, which can be encouraged to grow on agriculture land bunds, street sides and wastelands to supplement agro practices of farmers. A well-planned and executed agro practice along with Neem plantations shall make significant contribution to local energy needs at rural level.

\section{Appendix-1}

Methodology for calculating the total above ground biomass (TAB) and amount of $\mathrm{CO}_{2}$ sequestered by a tree per year

The rate of carbon sequestration depends on the growth characteristics of the tree species, the conditions 
for growth where the tree is planted, and the density of the tree's wood. It is high in the younger stages of tree growth, between 20 to 50 years. follows:

The process of calculating $\mathrm{CO}_{2}$ sequestration is as

1. Determine the total (green) weight of the tree.

2. Determine the dry weight of the tree.

3. Determine the weight of carbon in the tree.

4. Determine the weight of carbon dioxide sequestered in the tree

5. Determine the weight of $\mathrm{CO} 2$ sequestered in the tree per year

\section{Determine the total (green) weight of the tree}

The algorithm to calculate the weight of a tree is:

$\mathrm{W}=$ Above-ground weight of the tree in pounds

$\mathrm{D}=$ Diameter of the trunk in inches

$\mathrm{H}=$ Height of the tree in feet

For trees with $\mathrm{D}<11$ :

$\mathrm{W}=0.25 \mathrm{D} 2 \mathrm{H}$

For trees with $\mathrm{D}>=11$ :

$\mathrm{W}=0.15 \mathrm{D} 2 \mathrm{H}$

Depending on the species, the coefficient (e.g. 0.25 ) could change, and the variables $D$ and $H$ could be raised to exponents just above or below 1

However, these two equations could be seen as an "average" of all the species' equations.

The root system weighs about $20 \%$ as much as the above-ground weight of the tree.

Therefore, to determine the total green weight of the tree, multiply the above-ground weight of the tree by $120 \%$.

\section{Determine the dry weight of the tree}

The average tree is $72.5 \%$ dry matter and $27.5 \%$ moisture.

Therefore, to determine the dry weight of the tree, multiply the weight of the tree by $72.5 \%$.

\section{Determine the weight of carbon in the tree}

The average carbon content is generally $50 \%$ of the tree's total volume. Therefore, to determine the weight of carbon in the tree, multiply the dry weight of the tree by $50 \%$.

\section{Determine the weight of carbon dioxide sequestered in the tree}

- $\mathrm{CO} 2$ is composed of one molecule of Carbon and 2 molecules of Oxygen.

- The atomic weight of Carbon is 12.001115 .

- The atomic weight of Oxygen is 15.9994.

- The weight of $\mathrm{CO} 2$ is $\mathrm{C}+2 * 0=43.999915$.

- The ratio of $\mathrm{CO} 2$ to $\mathrm{C}$ is $43.999915 / 12.001115=3.6663$.

- Therefore, to determine the weight of carbon dioxide sequestered in the tree, multiply the weight of carbon in the tree by 3.6663

\section{Determine the weight of $\mathrm{CO} 2$ sequestered in the tree per year}

Divide the weight of carbon dioxide sequestered in the tree by the age of the tree.

Based on the above explained method $\mathrm{TAB}$ and $\mathrm{CO}_{2}$ sequestration of Azadiractha and has been calculated and tabulated (30 tree in random were selected from each block plantation for measurements)

TAB of Azadiractha

\begin{tabular}{|l|l|l|l|l|l|l|l|l|}
\hline \multicolumn{2}{|c|}{ (Average of 30 samples) } \\
\hline Factor & Age & $\begin{array}{l}\text { D } \\
\text { (in inches) }\end{array}$ & $\begin{array}{l}\mathrm{H} \\
\text { in } \mathrm{m}\end{array}$ & $\begin{array}{l}\text { W-Green } \\
\text { Weight in } \\
\text { lbs }\end{array}$ & $\begin{array}{l}\text { Average } \\
\text { Dry Weight } \\
\text { in lbs }\end{array}$ & $\begin{array}{l}\text { C02 } \\
\text { Sequestered } \\
\mathrm{yr}^{-1} \text { in lbs }\end{array}$ & $\begin{array}{l}\text { CO2 } \\
\text { Sequestered } \\
\mathrm{yr}^{-1} \mathrm{in} \mathrm{kg}^{\mathrm{kg}}\end{array}$ & $\begin{array}{l}\text { CO2 } \\
\text { Sequestered } \\
\mathrm{yr}^{-1} \mathrm{ha}^{-1} \mathrm{~kg}\end{array}$ \\
\hline 0.15 & 5.00 & 9.0 & 12.00 & 246.00 & 211.41 & 77.38 & 34.82 & 10445.77 \\
\hline
\end{tabular}

\section{References}

[1] ARAI, "Air Quality Monitoring Project-Indian Clean Air Programme (ICAP)," Draft report on "Emission Factor development for Indian Vehicles" as a part of Ambient Air Quality Monitoring and Emission, 2007.
[2] A. Karmakar, S. Karmakar and S. Mukherjee, "Biodiesel Production from Azadiractha Towards Feedstock Diversification: Indian perspective," Renewable and Sustainable Energy Reviews, vol.16, pp.1050-1060, 2012. 
[3] EF Aransiola, E Betiku, DI01 Ikhuomoregbe and TV Ojumu, "Production of Biodiesel from Crude Neem Oil Feedstock and Its Emissions from Internal Combustion Engines," African J. of Biotechnology, vol. 11, no. 22, pp. 6178-6186, 2012.

[4] Diesel Prices Bengaluru, "Historical Diesel Prices in Bangalore," Available:

http://www.mypetrolprice.com/6/Diesel-pricein-Bengaluru, 2012.

[5] Firewood, "Azadiractha Wood Calorific Value," Available: http://www.firewoods.in/products.htm, 2012.

[6] FAO, "Global Estimates of Gaseous Emissions of $\mathrm{NH}_{3}$, NO and $\mathrm{N}_{2} \mathrm{O}$ from Agricultural Land," FAO, Rome, 2013.

[7] Girish K and Shankara Bhat S., "Azadiractha - A Green Treasure," Electronic J. of Biology, vol. 4, no. 3, pp. 102-11, 2008.

[8] A.C. Girish, "Bio-Fuel Park - A mega model in Karnataka," 2010.

[9] H. Kleeberg and C. P. W. Zebitz, "Practice Oriented Results on Use and Production of Azadiractha Ingredients and Pheromones," in Proc. of the $9^{\text {th }}$ Workshop on March 13-15 held at Hohensolms, Germany, 2000.

[10] INSEDA- Azadiractha: Azadiractha, Booklet No. 457 Medicinal Plants: MPS -14, Available: http//:www.inseda.org/.../CD\%20.../53.../Azadira ctha\%20Cultivation-457.do, Accessed 30th November 2012.

[11] ISO 14010/44, "Environmental Management Life cycle Assessment Principles and Framework," Available: http://www.iso.org, 2006.

[12] IPCC-ID, IPCC Emission factor. Available: http://www.ipcc-nggip.iges.or.jp, 1622.

[13] IPCC-ID: 417274: IPCC Emission Factor, Available: $\quad$ http://www.ipccnggip.iges.or.jp, Accessed 11 July 2012

[14] Juerg, "Plastic Bags and Plastic Bottles - CO2 Emissions During their Lifetime," Available: http://timeforchange.org/plasticbags-andplastic-bottles-CO2- emissions, 2009.

[15] K. F. Yee, K. T. Tan, A. Z. Abdullah and K. T. Lee, "Life Cycle Assessment of Palm Biodiesel:
Revealing Facts and Benefits for Sustainability," Applied Energy, vol. 86, pp. 189-196, 2009.

[16] L. Graffman, "Arcata Plastic Bags," Available: http://www.appropedia.org//Arcata_plastic_bags , 2011.

[17] NOVODB-Azadiractha, "Azadiractha A Tree Borne Oilseed," Available: http://www.novodboard.com/AzadiracthaEng.pdf, 2009.

[18] Neem Foundation, "Economic Benefits of Neem Production,"

Available:

http://www.Neemfoundation.org/Neemarticles/economic-potential/industrial-uses/65economic-benefits-of-Neem-production.html, 2012.

[19] S.S. Ragit, S.K. Mohapatra, K. Kundu, and P. Gill, "Optimization of Neem Methyl Ester from Transesterification Process and Fuel Characterization as a Diesel Substitute," Biomass Bioenergy, vol.35, no. 3, pp. 1138-1144, 2011.

[20] T.V. Rao, G.P. Rao, and K.H.C. Reddy, "Experimental Investigation of Pongamia, Jatropha and Azadiractha Methyl Esters as Biodiesel on C.I. Engine," Jordan J. of Mech. and Ind. Eng., vol 2, pp. 117-122, 2008.

[21] R.R. Tan, A.B. Culaba, and M.R.I. Purvis, "Carbon Balance Implications of Coconut Biodiesel Utilization in the Philippine Automotive Transport Sector," Biomass \& Bio-energy, vol. 26, pp. 579-585, 2004.

[22] T. Altenburg, H. Dietz, M. Hahl, N. Nikolidakis, C. Rosendahl and K. Seelige, "Biodiesel in India Value Chain Organisation and Policy Options for Rural Development," German Develop. Inst., 2009.

[23] TNAU, "Organic Farming Manures," Available: http://agritech.tnau.ac./org_farm/orgfarm_manu re.html, 2012.

[24] W.M.J. Achten, E. Mathijs, and B. Muys, "Proposing a Life Cycle Land Use Impact Calculation Methodology," in Proc. of $6^{\text {th }}$ Int. Conf. on LCA in the Agri-Food Sector, Zurich, November 12-14, 2008.

[25] W.M.J. Achten, et al, "Life Cycle Assessment of Jatropha Biodiesel as Transportation Fuel in Rural India," Appl. Energy, vol. 87, pp. 3652-3660, 2010. 